\title{
Sumatran orangutan diets in the Late Pleistocene as inferred from dental microwear texture analysis
}

Julien Louys ${ }^{1 *}$, Yahdi Zaim², Yan Rizal ${ }^{2}$, Aswan $^{2}$, Mika Puspaningrum² ${ }^{2}$, Agus Trihascaryo ${ }^{2}$, Gilbert J. Price ${ }^{3}$, Ansley Petherick ${ }^{4}$, Elinor Scholtz ${ }^{5}$, Larisa R.G. DeSantis ${ }^{4,5, *}$

${ }^{1}$ Australian Research Centre for Human Evolution, Griffith University, Brisbane, Australia

${ }^{2}$ Paleontology and Quaternary Geology Research Group, Institut Teknologi Bandung, Indonesia

${ }^{3}$ School of Earth and Environmental Sciences, The University of Queensland, Brisbane, Queensland, Australia

${ }^{4}$ Department of Biological Sciences, Vanderbilt University, Nashville, TN, USA

${ }^{5}$ Department of Earth and Environmental Sciences, Vanderbilt University, Nashville, TN, USA

*To whom correspondence should be addressed: j.louys@griffith.edu.au, larisa.desantis@,vanderbilt.edu

\begin{abstract}
Orangutan (Pongo spp.) fossils have been found throughout much of Pleistocene Southeast Asia. Today, Pongo is restricted to three living species on the islands of Borneo and Sumatra. They are predominately frugivores, and during fruit masting events their diets can consist entirely of fruit. However, food procurement strategies between masting events differ between islands and thus species. Sumatran orangutans (Pongo abelii) are largely able to fall back on non-masting fruit species, such as figs, such that they can maintain higher quality diets compared to their Bornean counterparts (Pongo pygmaeus), who ingest more lower quality and tougher foods between mast events. However, diets of fossil orangutans remain largely unknown. We investigated the diets of Sumatran orangutans from the Pleistocene deposits of the Padang Highlands, western Sumatra, using dental microwear texture analysis. We tested whether the diets of the fossil species were similar to those of Bornean orangutans, all great apes generally, and macaques that occupy similar habitats to modern orangutans, in order to gain insights into palaeoenvironments present in western Sumatra. We found that fossil orangutans consumed foods less tough than modern Bornean Pongo pygmaeus, and thus presumably more fleshy fruits (absent of significant seed mastication). We found no differences in the amount of hard object feeding between modern and fossil orangutans. Taken together, we suggest that Pleistocene orangutans from western Sumatra had similar diets to Pongo abelii, indicating that masting events were not a significant contributing factor in their intake of fruit. Finally, we suggest anisotropy values in orangutan dental microwear may be an important marker for fruit masting events in the Pleistocene.
\end{abstract}

Keywords: Ngalau Gupin, Ngalau Sampit, Lida Ajer, Pandang Highlands, fruit masting, paleodiet 


\section{Introduction}

Orangutans belong to a subfamily of Primates dating back to the Miocene, the pongines, that also includes Sivapithecus, Gigantopithecus, and potentially Lufengpithecus and Ankarapithecus (Finarelli and Clyde 2004; Welker et al. 2019). Pleistocene orangutans (Pongo spp.) were formally distributed across Southeast Asia, from southern China in the north through to Java in the south (Jablonski and Whitford 1999; Louys et al. 2007; Louys 2008; Spehar et al. 2018). Relict populations of the three modern species, Pongo pygmaeus, P. abelii, and P. tapanuliensis, are now found only on the islands of Borneo and Sumatra. Explanations on the loss of their geographic range as well as the potential extinction of fossil species have largely been related to sustained habitat loss brought about by southern shifts in the tropical and sub-tropical zones and increased seasonality during Pleistocene glacial conditions (Jablonski and Whitford 1999; Louys et al. 2007; Louys 2008; Spehar et al. 2018).

Human interactions with orangutans are known from at least c. $50 \mathrm{ka}$, with evidence of orangutans and other primate hunting discernible from the archaeological deposits of Niah Cave, Borneo (Piper and Rabbett 2009). Earlier interactions are inferred based on the common presence of humans and orangutans in the Lida Ajer fossil deposits in Sumatra, dated to 62-72 ka (Westaway et al. 2017). However, a synthesis of palaeontological, archaeological, and palaeoecological data pertaining to orangutan and human interactions suggest that significant human influence on the distribution and extirpation of these apes became prevalent only in the last 10,000 years or so (Spehar et al. 2018).

In Sumatra, orangutans are found predominately north of Lake Toba and represented by $P$. abelii; the only substantiated exception is the second Sumatran species P. tapanuliensis, found in a $1000 \mathrm{~km}^{2}$ area of Batang Toru, South Tapanuli (Nater et al. 2017). Meanwhile, fossil orangutans 
on the island are only known from the Padang Highlands in west Sumatra. The largest collection of these are from the 'Dubois Caves', fossil deposits excavated by M. Eugene Dubois in the late $19^{\text {th }}$ Century (Dubois 1891). Orangutan fossils from the sites of Lida Ajer, Sibrambang, Djamboe, and several unnamed caves were described in detail by Hooijer (1948) and Drawhorn (1994). Additional orangutan fossils were subsequently reported from two nearby caves by Louys et al. (2017), Ngalau Gupin and Ngalau Sampit.

The evolutionary and biogeographical relationship between fossil and modern Sumatran orangutans has not been adequately addressed. It seems likely that the absence of fossil orangutans in the north of the island are a function of the lack of suitable fossil sites recorded in this region coupled with limited exploration. However, it is interesting that Binjai Tamieng, one of the only Quaternary sites known north of Lake Toba, records no fossil orangutans despite modern orangutans found nearby (Gruwier 2017). Presumably, orangutans were once found throughout the island and their current geographic range is a product of the extinction of the Padang Highland populations/species. Critical disparities in ecological or environmental tolerances between modern and fossil orangutans may have played a role in the latter's extinction. Notable differences between fossil specimens and modern species include generally larger tooth sizes and higher average enamel thickness in Pleistocene individuals (Hooijer 1948; Drawhorn 1994; Smith et al. 2011). These differences may be associated with processing harder, more brittle, or more abrasive foods in fossil orangutans (Smith et al. 2011).

Modern orangutans have the broadest range of plant species included in their diet of all the great apes (Russon et al. 2009). Nevertheless, they are predominately frugivores who prefer large quantities of fruit that are high in calories, soft in pulp, and occur in large crops (MacKinnon 1974; Galdikas 1988; Knott 1998; Djojosudharmo and van Schaik 1992; Leighton 1993). When fruit is 
unavailable, orangutans eat a variety of other food types including flowers, shoots and leaves, vines, pith, bark, insects, and occasionally smaller mammals (Hardus et al. 2012; Russon et al. 2009; Delgado and van Schaik 2000).

Dramatic fluctuations in fruit availability are common in Southeast Asia due to masting a phenomenon produced largely by dipterocarp and other canopy trees species that fruit in synchrony every 2-10 years (Ashton et al. 1988). Masting events are thought to be initiated by drier conditions and sharp drops in night-time temperatures associated with the El Niño Southern Oscillation (Ashton et al. 1988; Newbery et al. 1998; Wycherley 1973; Wich and van Schaik 2000). During masting events, orangutan diets may consist of 100\% fruit (Knott 1998; Kanamori et al. 2010). Between masting events, orangutans adopt one of two strategies related to the availability of fruit. In habitats dominated by dipterocarps, where fruiting is strongly controlled by masting events, orangutans adopt a sit and wait strategy in order to limit energy expenditure. In habitats where fruit is available more reliably, such as forests which have a high density of strangling figs, orangutans are constantly moving and feeding (Morrogh-Bernard et al. 2009).

Sumatra and Borneo differ significantly in terms of habitat productivity and climate, which have large impacts on the dietary ecology of orangutans living on these islands. Sumatran forests yield larger numbers of orangutan-preferred foods (Russon et al. 2009; Wich et al. 2006) and produce less severe masting effects on diet (Knott 1998; Delgado and van Schaik 2000; Wich et al. 2006). The net effect of these differences produces higher densities of Sumatran orangutans compared to Bornean, with Sumatran orangutans eating more high-quality foods (fruits), and less low-quality foods (bark, leaves) compared to their Bornean counterparts (Rijksen and Meijaard 1999; Delgado and van Schaik 2000; Russon et al. 2009). In Sumatran habitats where fruit has become scarce, such as anthropogenically degraded landscapes, Sumatran orangutans similarly 
spend more time eating bark than their conspecifics in more pristine environments (CampbellSmith et al. 2011).

Dental occlusal microwear (hereafter 'microwear') has been used to infer the diet and ecology of primates, past and present (e.g., Teaford 1985, 1988; Teaford and Glander 1991; Teaford and Runestad 1992; Teaford et al. 1996; Ungar and Teaford 1996; Ungar et al. 2004), including shedding light on modern and fossil pongines (e.g. Teaford and Walker, 1984; King et al. 1999; Ungar, 1994; Merceron et al. 2005, 2006; Scott et al. 2012). Dental microwear provides information pertaining to the most recent diet of an individual, prior to its death, i.e., 'the last supper effect' (Grine, 1986; Teaford \& Oyen 1989). Prior studies comparing orangutans with other Primates, as well as examining orangutans themselves, helped shed light on notable similarities and differences between species. Orangutans were found to have large numbers of microwear features as well as frequency of pits that were associated with hard or unripe fruit consumption and the processing of hard husked objects (King et al. 1999). While some studies found some effect of sex in orangutan microwear variables (Ungar, 1994; King et al. 1999), more recent studies have found no significant differences between the sexes (Merceron et al. 2005). In comparisons with other apes, orangutan microwear consistently compared most favorably with those of the chimpanzee (Teaford, 1988; King et al. 1999; Merceron et al. 2005). Early studies such as some of these, however, used a light or scanning electron microscope to count individual features (e.g., pits and scratches; Walker et al. 1978; Teaford and Walker 1984; Grine et al. 2002). While revealing, variability between human counters can pose challenges (Gordon 1988; Grine et al. 2002; Galbany et al., 2005; Scott et al. 2006; Schmidt 2010). Dental Microwear Texture Analysis (DMTA) analyzes dental microwear surfaces in three-dimensions using a scanning white light confocal microscope and scale sensitive fractal analysis (Ungar et al., 2003; Scott et al. 2005, 
2006). Wear surfaces are quantified in an automatic manner and textural attributes of a given surface are calculated the same, regardless of the observer.

In this study we examine the dental microwear of fossil orangutans from West Sumatra (Figure 1), comparing them to modern Bornean orangutans, as well as all other great apes, in order to infer dietary habitats of fossil orangutans. These sites are thought to represent rainforest habitats based on their faunal compositions (de Vos 1983; Louys and Meijaard, 2010; Westaway et al. 2017; Smith et al. this volume). We expect that lower quality diets associated with orangutans living in dipterocarp forests, and thus subject to mast fruit availability, will be higher in tougher foods such as bark that will be reflected by higher anisotropy values. We explore whether differences in the microwear variables present in teeth from well-dated Sumatran sites existed, and what this might indicate regarding ecological and environmental changes in Sumatra over the late Pleistocene.

\section{Materials and Methods}

\subsection{Specimens}

Specimens of extant ( $\mathrm{n}=12$ ) wild Pongo pygmaeus from the American Museum of Natural History (AMNH; New York City, NY, USA) and the Lee Kong Chian Natural History Museum (ZRC; Singapore) were sampled. Modern specimens are wild caught specimens from Borneo. More specific locality information was available for microwear analyses for four specimens: ZRC4742, ZRC4746L, and ZRC4750L are from Pontianak, west Kalimantan, and AMNH140426 is from Sandakan, Sabah. The taxonomic status of fossil orangutans is complicated and will be addressed more fully in a subsequent publication; for the purposes of this study all fossil orangutans are referred as Pongo sp. Fossil specimens (n=29) of Pongo sp. are from Lida Ajer (LA; n=6), Ngalau 
Gupin (NG; $n=22)$, and Ngalau Sampit $(N S ; n=1)$, representing a minimum of 2 , 4, and 1 individuals for each site, respectively (Table 1). Fossils from each site were initially screened for microwear analysis by eye and hand lens, with only the best-preserved teeth examined. This resulted in 3 teeth (33\%) discarded from Lida Ajer, and 30 teeth (54\%) from Ngalau Gupin. Casts were further assessed for quality, with an additional 4 molds (9\%) from Ngalau Gupin taken but not used in the final analysis. All fossils are housed in the Geology and Palaeontology collections

of the Institut of Teknologi Bandung (Indonesia), and molds in the DREAM lab of Vanderbilt University (USA).

The fossils from Lida Ajer were collected from the sinkhole at the rear of the cave and are presumed to have been reworked from cemented breccias chronologically constrained to 62-72 ka (Westaway et al. 2017) by Bayesian modelling derived from a combination of various numerical dating methods (U-series, Red TL, pIRIR, combined U-series/ESR). Sus and Rhinoceros teeth from Ngalau Gupin have been directly dated to $\sim 130$ ka using combined U-series/ESR method (Smith et al. in prep.), and the orangutan specimens from this site are considered coeval with these fossils. The specimen from Ngalau Sampit was collected from a breccia with a capping flowstone providing a minimum U-series age of $\sim 90 \mathrm{ka}$ (Louys et al. 2017). Data generated from extant specimens were added to and compared with published great ape and macaque data (Scott et al. 2012). The confocal microscopes used to generate both the published data and new specimen data are directly comparable (microscopes "Connie" and "Dolly", respectively; Arman et al., 2016, see Table 5 within this reference).

\subsection{Dental Microwear Texture Analysis (DMTA)}

DMTA has been used to distinguish diets in a broad range of extant taxa (e.g. ungulates, 
carnivorans, marsupials, and xenarthrans; Scott 2012, Jones and DeSantis, 2016, DeSantis et al. 2017a, 2017b, Haupt et al. 2013) including primates (e.g. Scott et al. 2005, 2006, 2012; Percher et al. 2018; Ungar et al. 2008, 2012). DMTA is also better able to distinguish dietary behavior as compared to 2D feature based methods (DeSantis et al. 2013). Primates that eat hard/brittle foods (e.g., fruit with hard pits, seeds) have higher complexity $(A s f c)$, while animals that eat tougher foods (e.g., grass, tough leaves) have higher anisotropy (epLsar; Ungar et al., 2003, 2007; Scott et al., 2005, 2006; DeSantis 2016). Texture fill volume (Tfv) is also useful for quantifying the size of features by comparing the volume filled by large $(10 \mu \mathrm{m}$ diameter $)$ and small $(2 \mu \mathrm{m}$ diameter $)$ square cuboids, with high $T f v$ values indicating potentially deeper and/or larger features (Scott et al 2006). $T f v$ typically parallels complexity, with the highest values occurring in taxa that also have higher complexity values; however, it does not yield significant differences between the great apes Gorilla and Pan (Scott et al. 2012). HAsfcs1 is another attribute that compares the complexity of one area of the surface to subdivided surfaces (i.e., a given surface is divided into 9x9 sub-surfaces, a total of 81 sub-surfaces, respectively), comparing individual sub-surfaces to the surface as a whole - potentially indicative of the size and variability in wear-causing particles (e.g., Scott et al., 2006, 2012; DeSantis, 2016).

"Phase II" facets (e.g. 9, x, 10n; Kay, 1977) were molded and analyzed to assess dietary behavior in the great apes examined (Table 1), standardizing the same position as best as possible among sampled teeth (based on wear). Teeth were cleaned with cotton swabs and acetone, after which a polyvinylsiloxane dental impression material (President's Jet, Coltene-Whaledent Corp., Alstatten, Switzerland) was applied to their occlusal surfaces. The molds were subsequently cast using a high-resolution epoxy (Epotek 301, Epoxy Technologies Corp., Billerica, MA, USA). Casts were scanned with Sensofar PLu neox optical profiler (Solarius Development, Inc., 
Sunnyvale, CA) using a $100 \times$ objective lens at Vanderbilt University. These data were compared to extant primate data from this study (scanned on the confocal noted above at Vanderbilt) and published data (i.e., Scott et al., 2012) that were scanned on a Sensofar Plu white-light scanning confocal profiler (Solarius Development, Inc., Sunnyvale, CA) using a 100× objective lens at the University of Arkansas. While it is important to consider differences in DMTA attribute values between microscopes, all new analyses were performed on "Dolly" (at Vanderbilt University); however, DMTA attributes are indistinguishable between "Dolly" and "Connie" (at the University of Arkansas; see Arman et al., 2016 and Table 5 within). Further, the same exact areas and methods were used for all analyses here conducted and referenced.

A total area of $204 \times 276 \mu \mathrm{m}^{2}$ was scanned, a $2 \times 2$ grid (a total of four scans); the median attribute value of all four scans is reported for each specimen (per Ungar et al. 2003, Scott et al. 2005, 2006). All tooth surfaces underwent scale-sensitive fractal analysis (SSFA) via analysis of tooth surfaces using both toothfrax and Sfrax (Surfract Corp., http://www.surfract.com/) software; the median value of the four scans was used to represent a given specimen. The scans were analyzed for complexity $(A s f c)$, anisotropy (epLsar), textural fill volume ( $T f v)$, and heterogeneity (HAsfc81). Examples of microwear attributes are displayed in Figure 2.

\subsection{Statistical analysis}

DMTA values were primarily non-normally distributed (Table 2), non-parametric tests were used for most comparisons, as other studies in occlusal microtexture (e.g. Scott et al. 2005, 2012). Pongo pygmaeus and fossil Pongo sp. were compared using Mann-Whitney U-tests (nonparametric); additionally, $A s f c$ values were also compared using parametric t-tests as these data were normally distributed. We used Kruskal-Wallis tests and Dunn's procedure to compare all 
extant taxa to each other and to Pongo sp.; and to compare modern Pongo with Pongo sp. from Ngalau Gupin and Lida Ajer, with differences between groups assessed via post-hoc MannWhitney U comparisons. Further, Pongo sp. from Ngalau Gupin and Lida Ajer were also directly compared via Mann-Whitney U-tests. Significance was evaluated at $\alpha=0.05$.

\section{Results}

Dental microwear data for Pongo pygmaeus analysed in the present work and fossil specimens of Pongo sp. (in addition to relevant great ape data) included in Supplemental Table 1, are summarized in Table 2 and graphically represented in Figure 3, with detailed specimen data noted in Table 1. Published data (Scott et al. 2012) used in these analyses are also summarized in Table 2 and noted in Supplemental Table 1.

As both prior comparison and our comparisons (which includes additional Pongo pygmaeus data) of the two species of Gorilla (i.e., Gorilla beringei and Gorilla gorilla) with Pan troglodytes and Pongo pygmaeus are indistinguishable from comparisons at the genus level (Scott et al., 2012), both species of Gorilla were combined in subsequent comparisons of modern and fossil taxa. All extant great apes (Gorilla, Pan, and Pongo) are indistinguishable in Asfc and Tfv values ( $>0.1$; Fig. 3A). Pan has significantly lower epLsar than both Gorilla $(\mathrm{p}=0.034)$ and Pongo $(\mathrm{p}=0.008$; Fig. 3A). Pan also has significantly higher HAsfc 81 than both Gorilla $(\mathrm{p}=0.032)$ and Pongo $(\mathrm{p}=0.013)$. For completeness, Pongo pygmaeus was also compared to the crab-eating macaque Macaca fascicularis (from Scott et al. 2012) as they occupy similar habitats. These taxa are indistinguishable in $A s f c$, epLsar, and $H A s f c 81$ values ( $>0.05$ for all; Fig. 3B). Pongo pygmaeus has significantly lower Tfv than Macaca fascicularis ( $\mathrm{p}=0.029$ ); though caution should be taken when comparing these taxa due to differences in tooth morphology. 
Fossil specimens of Pongo (i.e. Pongo sp.) are indistinguishable in Asfc from all extant apes examined here (Gorilla, Pan, and Pongo) including both parametric and non-parametric comparisons with just Pongo pygmaeus ( $\mathrm{p}>0.1$; Fig. 3C). Pongo sp. has significantly lower epLsar than modern Pongo pygmaeus ( $\mathrm{p}=0.015$; and, $\mathrm{p}=0.022$ when only compared to Pongo pygmaeus), significantly lower $T f v$ than Gorilla $(\mathrm{p}=0.048)$, and significantly lower $H A s f c 81$ than all extant taxa ( $<<0.0001$ for Gorilla, Pan, and Pongo pygmaeus when comparing only Pongo pygmaeus and Pongo sp.; $\mathrm{p}=0.0002$ for Pongo pygmaeus when comparing all taxa here examined). When separating out Pongo sp. from Ngalau Gupin and Lida Ajer, compared to Pongo pygmaeus, no significant differences were found for $A s f c$ or $T f v(\mathrm{p} \geq 0.2)$. Differences for epLsar exceeded $\alpha=0.05$ $(\mathrm{p}=0.086$ ), with post-hoc tests revealing significantly lower values in Ngalau Gupin Pongo sp. than Pongo pygmaeus $(\mathrm{p}=0.033)$. Both Lida Ajer and Ngalau Gupin Pongo sp. have significantly lower HAsfc81 values than Pongo pygmaeus $(\mathrm{p}=0.003$ and $\mathrm{p}<0.001$, respectively). There are no significant differences in any DMTA attribute ( $A s f c, e p L s a r, T f v, H A s f c 81$ ) between Pongo sp. from Ngalau Gupin and Lida Ajer localities (though low sample size at Lida Ajer reduces statistical power). Proportions of complex $(A s f c>2)$ and anisotropic values (epLsar $>0.005)$ for specimens of each taxon are note in Fig. 3D.

\section{Discussion}

Our results suggest that the West Sumatran fossil orangutans ate more fruit than extant orangutans from Borneo, consistent with differences in diets observed between P. pygmaeus and $P$. abelii. Soft fruit eaters have lower HAsfc81 values and lower epLsar values (Scott et al., 2012), which the fossil orangutans display, and that may be explained by a heavier reliance on higher-quality foods. In this, they are similar to values recorded for Pan (for both $A s f c$ and epLsar, but not $T f v$ and 
$H A s f c$ ), who preferentially seek out soft fruits when foraging (Scott et al. 2012; Wrangham et al. 1997). Higher epLsar values in Pongo pygmaeus are likely the result of higher intake of tougher foods such as the inner cambium layer of bark and leaves, fallback foods commonly ingested between masting events (Vogel et al. 2009). Confirmation of this requires a comparative microwear sample of modern Sumatran and Tapanuli orangutans. The differences in HAsfc81 observed between modern and fossil orangutans could also be related to the presence of dipterocarp forests and irregular fruit masting events today. We found no significant differences in either $A s f c$ or $T f v$ between fossil and modern Bornean orangutans, suggesting that the degree of hard object feeding was similar between extinct and modern Bornean taxa. Taken together, our results suggest that fossil Sumatran orangutan diets may have included more fruit than Bornean orangutans, similar to that observed in modern Sumatran species (Pongo abelii; Taylor 2006; Wich et al. 2006; Morrogh-Bernard et al. 2009).

Ngalau Gupin is the older site examined here, with the fossils from this cave likely dating to the end of Marine Isotope Stage (MIS) 6 or the beginning of MIS5 ( 130 ka; Lisiecki and Raymo 2005). Lida Ajer on the other hand, likely dates to the end of MIS5 to the beginning of MIS4 ( 71 ka; Lisiecki and Raymo 2005). Thus, these fossils bracket MIS5, a period of warm and wet climate and vegetation. Ngalau Sampit dates to MIS5 ( 100 ka; Lisiecki and Raymo 2005), but only a single orangutan fossil is reported from this site so far. Despite fossil specimens originating from sites occurring during times characterized by disparate climatic regimes, the diets of fossil Pongo sp. from these sites were likely similar (based on indistinguishable DMTA attribute values, $\mathrm{p} \geq 0.37$ ). While the Lida Ajer orangutan sample was restricted to six individuals, and hence sample size may be a challenge, there is no indication of distinct diets in these individuals compared to earlier orangutans living in the Padang Highlands. Thus, the habitats available to 
orangutans in the Padang Highlands inferred from microwear data remained unchanged through at least one glacial/interglacial cycle of the Pleistocene. This contrasts with most of Southeast Asia, where numerous lines of evidence suggest savannah environments replaced rainforests throughout the region during glacials, but especially in the proposed 'central savannah corridor' of Sundaland (Heaney 1991; Bird et al. 2005; Louys and Meijaard 2010; Wurster et al. 2010, 2019; Bacon et al. 2018; Suraprasit et al. 2019). Such environmental fluctuations have long been suspected as detrimental to rainforest taxa (e.g. Louys et al. 2007, Louys 2008), with rainforest margins in Borneo and Sumatra potentially acting as refugia for orangutans during glacial periods. However, a recent re-evaluation of orangutan palaeoecology and distributions suggest that these apes may have been more resilient to environmental changes that previously appreciated (Spehar et al. 2018). The factors involved in the orangutan extirpation or extinction of orangutans from western Sumatra remain unresolved.

If the modern Bornean orangutan diets are similarly unchanged since the Pleistocene, then our results suggest that the modern dietary differences observed between Sumatran and Bornean orangutans has a long geological history. However, given that modern Sumatran orangutans ingest tougher foods and less fruits in habitats negatively impacted by people (Campbell-Smith et al. 2011), all species of orangutans are likely flexible foragers in the face of environmental or habitat changes. This finding suggests that it is fruit availability, not species identity, that determines the dominant microwear signal in orangutan teeth, and gives us confidence that the microwear signal preserved in our fossil specimens accurately reflects local environmental conditions, even if we cannot yet confidently allocate our specimens to any particular species of orangutan. Dietary information is a key component to comprehending how ecological conditions affect orangutan distributions, social structures, and behavior (Russon et al. 2009). Thus, further examination of 
fossil orangutan diets may provide greater insights into the evolutionary history of these apes. With a broad distribution across much of Southeast Asia, examining microwear of fossil orangutans may also provide insights into past environments in the region more broadly, with differences in anisotropy a potential marker for reconstructing the history and distribution of fruit masting in the tropics.

\section{Conclusions}

Understanding orangutan diets today and in the past is an important first step in reconstructing orangutan adaptations to different environmental conditions. We demonstrate that fossil orangutans from the Padang Highlands consumed foods that were less tough than that consumed by extant modern orangutans from Borneo. This is comparable to dietary differences observed between Pongo pygmaeus on Borneo and Pongo abelii from Sumatra. Differences in diets between modern and fossil orangutans suggest the environment differences between Sumatra and Borneo present today also existed during the Pleistocene. No dietary changes were observed in our fossil samples throughout the Pleistocene, and insights into the cause of extinction of orangutan populations in the Padang Highlands remain elusive. Addressing this latter question will require further data and more well-dated sites from the region, particularly those following human arrival on the island, as well as further investigations into orangutan fossil taxonomy to resolve the species identity of fossil specimens. Nevertheless, our study provides an important insight into ancient orangutan diets, filling a key gap in understanding their evolutionary history.

\section{Acknowledgments}


We would like to thank Eleanor Hoeger, Robert Voss (American Museum of Natural History, New York), and Lim Kok Peng (Lee Kong Chian Natural History Museum, Singapore) for access to museum specimens. Holly Smith and Jerry Drawhorn are thanked for their assistance

during fieldwork, and HS for photos of specimens. Funding was provided by an Australian Research Council Future Fellowship FT160100450 (to Louys), and EAR grant 1053839 and funding from Vanderbilt University (to DeSantis). Two anonymous reviewers and the editor provided valuable feedback that helped improve this manuscript.

\section{References}

Arman, S.D., Ungar, P.S., Brown, C.A., DeSantis, L.R.G., Schmidt, C., Prideaux, G.J., 2016. Minimizing intermicroscope variability in dental microwear texture analysis. Surf. Topogr.: Metrol. Prop. 4, 024007. https://doi.org/10.1088/2051-672X/4/2/024007

Ashton, P.S., Givnish, T.J., Appanah, S., 1988. Staggered flowering in the Dipterocarpaceae: new insights into floral induction and the evolution of mast fruiting in the aseasonal tropics. Am. Nat., 132, 44-66.

Bacon, A.M., Duringer, P., Westaway, K., Joannes-Boyau, R., Zhao, J.X., Bourgon, N., Dufour, E., Pheng, S., Tep, S., Ponche, J.L. and Barnes, L., 2018. Testing the savannah corridor hypothesis during MIS2: The Boh Dambang hyena site in southern Cambodia. Quat. Int. 464, 417-439.

Bird, M.I., Taylor, D., Hunt, C., 2005. Palaeoenvironments of insular Southeast Asia during the Last Glacial Period: a savanna corridor in Sundaland?. Quat. Sci. Rev., 24, 2228-2242.

Campbell-Smith, G., Campbell-Smith, M., Singleton, I. and Linkie, M., 2011. Raiders of the lost bark: Orangutan foraging strategies in a degraded landscape. PloS one, 6(6). https://doi.org/10.1371/journal.pone.0020962

Delgado Jr, R.A., Van Schaik, C.P., 2000. The behavioral ecology and conservation of the orangutan (Pongo pygmaeus): a tale of two islands. Evol. Anthropol.: Issues, News, Rev., 9, 201-218. https://doi.org/10.1002/1520-6505(2000)9:5<201::AID-EVAN2>3.0.CO;2-Y

DeSantis, L.R.G., 2016. Dental microwear textures: reconstructing diets of fossil mammals. Surf. Topogr.: Metrol. Prop. 4, 023002. https://doi.org/10.1088/2051-672X/4/2/023002

DeSantis, L.R.G., Scott, J.R., Schubert, B.W., Donohue, S.L., McCray, B.M., Van Stolk, C.A., Winburn, A.A., Greshko, M.A., O'Hara, M.C., 2013. Direct comparisons of 2D and 3D dental microwear proxies in extant herbivorous and carnivorous mammals. PLoS ONE 8, e71428. https://doi.org/10.1371/journal.pone.0071428

DeSantis, L.R.G., Schubert, B.W., Schmitt-Linville, E., Ungar, P.S., Donohue, S.L., Haupt, R.J., 2015. Dental microwear textures of carnivorans from the La Brea Tar Pits, California, and potential extinction implications. In: Harris, J.M. (Ed.), La Brea and Beyond: The Paleontology of Asphalt-Preserved Biotas, Science Series. Natural History Museum of Los Angeles County, pp. 37-52.

DeSantis, L.R.G., Tseng, Z.J., Liu, J., Hurst, A., Schubert, B.W., Jiangzuo, Q., 2017a. Assessing niche conservatism using a multiproxy approach: dietary ecology of extinct and extant spotted hyenas. Paleobiol. 43, 286-303. https://doi.org/10.1017/pab.2016.45

DeSantis, L.R.G., Field, J.H., Wroe, S., Dodson, J.R., 2017b. Dietary responses of Sahul (Pleistocene AustraliaNew Guinea) megafauna to climate and environmental change. Paleobiol. 43, 181-195. https://doi.org/10.1017/pab.2016.50

De Vos, J., 1983. The Pongo faunas from Java and Sumatra and their significance for biostratigraphical and paleoecological interpretations. Proc. Koninklke Nederlandse Akademie van Wetenschappen Ser. B. 86, 417425 . 
Djojosudharmo, S., van Schaik, C.P., 1992. Why are orangutans so rare in the highlands. Trop Biodivers, 1, 11-22.

Drawhorn, G. M., 1994 The Systematics and Paleodemography of Fossil Orangutans. PhD Thesis, Univ. California, Davis.

Dubois, E., 1891 Voorlopig bericht omtrent het onderzoek naar de Pleistocene en Tertiaire vertebraten-fauna van Sumatra en Java, gedurende het jaar 1890. Nat. Tijdschr. Ned. Indië 51, 93-100

Finarelli, J.A. and Clyde, W.C., 2004. Reassessing hominoid phylogeny: evaluating congruence in the morphological and temporal data. Paleobiology, 30(4), 614-651.

Galbany, J., Martínez, L.M., López - Amor, H.M., Espurz, V., Hiraldo, O., Romero, A., Juan, J. de, Pérez - Pérez, A., 2005. Error rates in buccal-dental microwear quantification using scanning electron microscopy. Scanning

Galdikas, B.M., 1988. Orangutan diet, range, and activity at Tanjung Puting, Central Borneo. Int. J. Primatol., 9, 135. https://doi.org/10.1007/BF02740195

Gordon, K.D., 1988. A review of methodology and quantification in dental microwear analysis. Scanning Microsc. 2, 1139-1147.

Grine, F. E. 1986. Dental evidence for dietary differences in Australopithecus and Paranthropus: a quantitative analysis of permanent molar microwear. J. Hum. Evol. 15, 783-822.

Grine, F.E., Ungar, P.S., Teaford, M.F., 2002. Error rates in dental microwear quantification using scanning electron microscopy. Scanning 24, 144-153. https://doi.org/10.1002/sca.4950240307

Gruwier, B.J., 2017. The large vertebrate remains from Binjai Tamieng (Sumatra, Indonesia). J. Indo-Pacific Archaeol., 41, 22-29. https://doi.org/10.7152/jipa.v41i0.15027

Hardus, M.E., Lameira, A.R., Zulfa, A., Atmoko, S.S.U., de Vries, H. and Wich, S.A., 2012. Behavioral, ecological, and evolutionary aspects of meat-eating by Sumatran orangutans (Pongo abelii). Int. J. Primat., 33, 287304. https://doi.org/10.1007/s10764-011-9574-z

Haupt, R.J., DeSantis, L.R.G., Green, J.L., Ungar, P.S., 2013. Dental microwear texture as a proxy for diet in xenarthrans. J. Mammal. 94, 856-866. https://doi.org/10.1644/12-MAMM-A-204.1

Heaney, L.R., 1991. A synopsis of climatic and vegetational change in Southeast Asia. In Tropical Forests and Climate (pp. 53-61). Springer, Dordrecht.

Hooijer, D. A., 1948 Prehistoric teeth of man and of the orang-utan from central Sumatra, with notes on the fossil orang-utan from Java and Southern China. Zool. Meded. 29, 175-301.

Jablonski, N.G., Whitfort, M.J., 1999. Environmental change during the Quaternary in East Asia and its consequences for mammals. Rec. West. Aust. Mus., 57, 307-315.

Jones, D.B., Desantis, L.R.G., 2016. Dietary ecology of the extinct cave bear: evidence of omnivory as inferred from dental microwear textures. Acta Palaeontol. Pol. 61, 735-741. https://doi.org/10.4202/app.00253.2016

Jones, D.B., Desantis, L.R.G., 2017. Dietary ecology of ungulates from the La Brea tar pits in southern California: a multi-proxy approach. Palaeogeogr. Palaeoclimatol. Palaeoecol. 466, 110-127. https://doi.org/10.1016/j.palaeo.2016.11.019

Karriger, W.M., Schmidt, C.W., 2016. Dental microwear texture analysis of Croatian Neandertal molars. PaleoAnthropol. 172-184.

Kay, R.F., 1977. The evolution of molar occlusion in the Cercopithecidae and early catarrhines. Am. J. Phys. Anthropol. 46, 327-352. https://doi.org/10.1002/ajpa.1330460213

King, T., Aiello, L.C. and Andrews, P., 1999. Dental microwear of Griphopithecus alpani. J. Hum. Evol. 36(1), 331.

Knott, C.D., 1998. Changes in orangutan caloric intake, energy balance, and ketones in response to fluctuating fruit availability. Int. J. of Primatol., 19, 1061-1079. https://doi.org/10.1023/A:1020330404983

Leighton, M., 1993. Modeling dietary selectivity by Bornean orangutans: evidence for integration of multiple criteria in fruit selection. Int. J. of Primatol., 14, 257-313. https://doi.org/10.1007/BF02192635

Lisiecki, L. E. and Raymo, M. E., 2005. A Pliocene-Pleistocene stack of 57 globally distributed benthic $\mathrm{d}^{18} \mathrm{O}$ records. Paleoceanogr. 20, PA1003, doi:10.1029/2004PA001071

Louys, J., 2008. Quaternary extinctions in southeast Asia. In Mass extinction (pp. 159-189). Springer, Berlin, Heidelberg.

Louys, J. and Meijaard, E., 2010. Palaeoecology of Southeast Asian megafauna - bearing sites from the Pleistocene and a review of environmental changes in the region. J. Biogeogr. 37(8), 1432-1449.

Louys, J., Curnoe, D., Tong, H., 2007. Characteristics of pleistocene megafauna extinctions in Southeast Asia. Palaeogeogr. Palaeoclimatol. Palaeoecol., 243, 152-173. https://doi.org/10.1016/j.palaeo.2006.07.011

Louys, J., Kealy, S., O'Connor, S., Price, G.J., Hawkins, S., Aplin, K., Rizal, Y., Zaim, J., Mahirta, Tanudirjo, D.A., Santoso, W.D., Hidayah, A.R., Trihascaryo, A., Wood, R., Bevitt, J., Clark, T., 2017. Differential 
preservation of vertebrates in Southeast Asian caves. Int. J. Speleol. 46: 379-408.

https://doi.org/10.5038/1827-806X.46.3.2131

MacKinnon, J., 1974. The behaviour and ecology of wild orang-utans (Pongo pygmaeus). Anim. Behav., 22, 3-74. https://doi.org/10.1016/S0003-3472(74)80054-0

Merceron, G., Blondel, C., Bonis, L.D., Koufos, G.D., Viriot, L., 2005. A new method of dental microwear analysis: application to extant primates and Ouranopithecus macedoniensis (Late Miocene of Greece). Palaios 20, 551-561. https://doi.org/10.2110/palo.2004.p04-17

Merceron, G., Taylor, S., Scott, R., Chaimanee, Y. and Jaeger, J.J., 2006. Dietary characterization of the hominoid Khoratpithecus (Miocene of Thailand): evidence from dental topographic and microwear texture analyses. Naturwissenschaften, 93(7), 329-333.

Morrogh-Bernard, H.C., Husson, S.J., Knott, C.D., Wich, S.A., van Schaik, C.P., van Noordwijk, M.A., LackmanAncrenaz, I., Marshall, A.J., Kanamori, T., Kuze, N. and bin Sakong, R., 2009. Orangutan activity budgets and diet. In: Wich, S.A., Setia, T.M. and van Schaik, C.P. eds. Orangutans: geographic variation in behavioral ecology and conservation. OUP Oxford, pp.119-133.

Nater, A., Mattle-Greminger, M.P., Nurcahyo, A., Nowak, M.G., De Manuel, M., Desai, T., Groves, C., Pybus, M., Sonay, T.B., Roos, C., Lameira, A.R., 2017. Morphometric, behavioral, and genomic evidence for a new orangutan species. Curr. Biol., 27, 3487-3498. https://doi.org/10.1016/j.cub.2017.09.047

Newbery, D.M., Chuyong, G.B., Zimmermann, L., 2006. Mast fruiting of large ectomycorrhizal African rain forest trees: importance of dry season intensity, and the resource-limitation hypothesis. New Phytol., 170, 561579. https://doi.org/10.1111/j.1469-8137.2006.01691.x

Percher, A.M., Merceron, G., Nsi Akoue, G., Galbany, J., Romero, A. and Charpentier, M.J., 2018. Dental microwear textural analysis as an analytical tool to depict individual traits and reconstruct the diet of a primate. Am. J. Phys. Anthropol. 165(1), 123-138.

Piper, P.J., Rabett, R.J., 2009. Hunting in a tropical rainforest: evidence from the Terminal Pleistocene at Lobang Hangus, Niah Caves, Sarawak. Int. J. Osteoarchaeol., 19(4), 551-565. https://doi.org/10.1002/oa.1046

Rijksen, H.D., Meijaard, E., 1999. Our vanishing relative: the status of wild orang-utans at the close of the twentieth century. Dordrecht: Kluwer Academic Publishers.

Russon, A.E., Wich, S.A., Ancrenaz, M., Kanamori, T., Knott, C.D., Kuze, N., Morrogh-Bernard, H.C., Pratje, P., Ramlee, H., Rodman, P., Sawang, A., 2009. Geographic variation in orangutan diets. In: Wich, S.A., Setia, T.M. and van Schaik, C.P. eds. Orangutans: geographic variation in behavioral ecology and conservation. OUP Oxford, pp.135-156.

Sanson, G.D., Miller, W.A., 1979. Mechanism of molar progression in macropods. Anat. Rec. 193, 674.

Schmidt, C.W., 2010. On the relationship of dental microwear to dental macrowear. Am. J. Phys. Anthropol. 142, 67-73. https://doi.org/10.1002/ajpa.21197

Scott, J.R., 2012. Dental microwear texture analysis of extant African Bovidae. Mammalia 76, 157-174.

Scott, R.S., Ungar, P.S., Bergstrom, T.S., Brown, C.A., Grine, F.E., Teaford, M.F., Walker, A., 2005. Dental microwear texture analysis shows within-species diet variability in fossil hominins. Nature 436, 693-695. https://doi.org/10.1038/nature03822

Scott, R.S., Ungar, P.S., Bergstrom, T.S., Brown, C.A., Childs, B.E., Teaford, M.F., Walker, A., 2006. Dental microwear texture analysis: technical considerations. J. Hum. Evol. 51, 339-349. https://doi.org/10.1016/j.jhevol.2006.04.006

Scott, R.S., Teaford, M.F., Ungar, P.S., 2012. Dental microwear texture and anthropoid diets. Am. J. Phys. Anthropol. 147, 551-579. https://doi.org/10.1002/ajpa.22007

Smith, T.M., Bacon, A.M., Demeter, F., Kullmer, O., Nguyen, K.T., de Vos, J., Wei, W., Zermeno, J.P., Zhao, L., 2011. Dental tissue proportions in fossil orangutans from mainland Asia and Indonesia. Hum. Orig. Res., 1, e1-e1. https://doi.org/10.4081/hor.2011.3

Spehar, S.N., Sheil, D., Harrison, T., Louys, J., Ancrenaz, M., Marshall, A.J., Wich, S.A., Bruford, M.W., Meijaard, E., 2018. Orangutans venture out of the rainforest and into the Anthropocene. Sci. Adv., 4, e1701422. https://doi.org/10.1126/sciadv.1701422

Suraprasit, K., Jongautchariyakul, S., Yamee, C., Pothichaiya, C. and Bocherens, H., 2019. New fossil and isotope evidence for the Pleistocene zoogeographic transition and hypothesized savanna corridor in peninsular Thailand. Quatern. Sci. Rev. 221, 105861

Taylor, A.B., 2006. Feeding behavior, diet, and the functional consequences of jaw form in orangutans, with implications for the evolution of Pongo. J. Hum. Evol. 50, 377-393. https://doi.org/10.1016/j.jhevol.2005.10.006 
Teaford, M.F., 1985. Molar microwear and diet in the genus Cebus. Am. J. Phys. Anthropol. 66, 363-370. https://doi.org/10.1002/ajpa.1330660403

Teaford, M.F., 1988. A review of dental microwear and diet in modern mammals. Scanning Microsc. 2, 1149-1166.

Teaford M.F. and Oyen, O.J., 1989. In vivo and in vitro turnover in dental microwear. Am. J. Phys. Anthropol. 80(4), 447-60.

Teaford, M.F. and Walker, A., 1984. Quantitative differences in dental microwear between primate species with different diets and a comment on the presumed diet of Sivapithecus. Am. J. Phys. Anthropol. 64(2), 191200.

Teaford, M.F., Glander, K.E., 1991. Dental microwear in live, wild-trapped Alouatta palliata from Costa Rica. Am. J. Phys. Anthropol. 85, 313-319. https://doi.org/10.1002/ajpa.1330850310

Teaford, M.F., Runestad, J.A., 1992. Dental microwear and diet in Venezuelan primates. Am. J. Phys. Anthropol. 88, 347-364. https://doi.org/10.1002/ajpa.1330880308

Teaford, M.F., Walker, A., 1984. Quantitative differences in dental microwear between primate species with different diets and a comment on the presumed diet of Sivapithecus. Am. J. Phys. Anthropol. 64, 191-200. https://doi.org/10.1002/ajpa.1330640213

Teaford, M.F., Maas, M.C., Simons, E.L., 1996. Dental microwear and microstructure in early Oligocene primates from the Fayum, Egypt: implications for diet. Am. J. Phys. Anthropol. 101, 527-543. https://doi.org/10.1002/(SICI)1096-8644(199612)101:4<527::AID-AJPA7>3.0.CO;2-S

Ungar, P.S., 1994. Incisor microwear of Sumatran anthropoid primates. Am. J. Phys. Anthropol. 94(3), 339-363.

Ungar, P., Teaford, M., Kay, R., 2004. Molar microwear and shearing crest development in Miocene catarrhines. Anthropol. 42, 21-35.

Ungar, P.S., Teaford, M.F., 1996. Preliminary examination of non-occlusal dental microwear in anthropoids: implications for the study of fossil primates. Am. J. Phys. Anthropol. 100, 101-113. https://doi.org/10.1002/(SICI)1096-8644(199605)100:1<101::AID-AJPA10>3.0.CO;2-4

Ungar, P.S., Brown, C.A., Bergstrom, T.S., Walker, A., 2003. quantification of dental microwear by tandem scanning confocal microscopy and scale-sensitive fractal analyses. Scanning 25, 185-193. https://doi.org/10.1002/sca.4950250405

Ungar, P.S., Merceron, G., Scott, R.S., 2007. Dental microwear texture analysis of Varswater bovids and Early Pliocene paleoenvironments of Langebaanweg, Western Cape Province, South Africa. J. Mammal. Evol. 14, 163-181. https://doi.org/10.1007/s10914-007-9050-x

Ungar, P.S., Grine, F.E., Teaford, M.F., 2008. Dental microwear and diet of the Plio-Pleistocene hominin Paranthropus boisei. PLoS ONE 3, e2044. https://doi.org/10.1371/journal.pone.0002044

Ungar, P.S., Krueger, K.L., Blumenschine, R.J., Njau, J., Scott, R.S., 2012. Dental microwear texture analysis of hominins recovered by the Olduvai Landscape Paleoanthropology Project, 1995-2007. J. Hum. Evol. 63, 429-437. https://doi.org/10.1016/j.jhevol.2011.04.006

Vogel, E.R., Haag, L., Mitra-Setia, T., Van Schaik, C.P., Dominy, N. J., 2009. Foraging and ranging behavior during a fallback episode: Hylobates albibarbis and Pongo pygmaeus wurmbii compared. Am. J. Phys. Anthropol. 140, 716-726. https://doi.org/10.1002/ajpa.21119

Walker, A., Hoeck, H.N., Perez, L., 1978. Microwear of mammalian teeth as an indicator of diet. Science (New York, N.Y.) 201, 908-910. https://doi.org/10.1126/science.684415

Welker, F., Ramos-Madrigal, J., Kuhlwilm, M., Liao, W., Gutenbrunner, P., de Manuel, M., Samodova, D., Mackie, M., Allentoft, M.E., Bacon, A.M. and Collins, M.J., 2019. Enamel proteome shows that Gigantopithecus was an early diverging pongine. Nature, 576(7786), 262-265.

Westaway, K.E., Louys, J., Due Awe, R., Morwood, M.J., Price, G.J., Zhao, J.-x., Aubert, M., Joannes-Boyau, R., Smith, T., Skinner, M.M., Compton, T., Bailey, R.M., van den Bergh, G.D., de Vos, J., Pike, A.W.G, Stringer, C., Saptomo, E.W., Rizal, Y., Zaim, J., Santoso, W.D., Trihascaryo, A., Kinsley, L., Sulistyanto, B., 2017. An early modern human presence in Sumatra 73,000-63,000 years ago. Nature, 548, 322-325. https://doi.org/10.1038/nature23452

Wich, S.A., Van Schaik, C.V., 2000. The impact of El Nino on mast fruiting in Sumatra and elsewhere in Malesia. J. Trop. Ecol., 16, 563-577. https://doi.org/10.1017/S0266467400001577

Wich, S.A., Utami-Atmoko, S.S., Setia, T.M., Djoyosudharmo, S., Geurts, M.L., 2006. Dietary and energetic responses of Pongo abelii to fruit availability fluctuations. Int. J. Primatol., 27, 1535-1550. https://doi.org/10.1007/s10764-006-9093-5

Wrangham, R.W., Conklin-Brittain, N.L., Hunt, K.D., 1998. Dietary response of chimpanzees and Cercopithecines to seasonal variation in fruit abundance. I. Antifeedants. Int. J. Primatol., 19, 949-970. https://doi.org/10.1023/A:1020318102257 
Wurster, C.M., Bird, M.I., Bull, I.D., Creed, F., Bryant, C., Dungait, J.A. and Paz, V., 2010. Forest contraction in north equatorial Southeast Asia during the Last Glacial Period. Proc. Natl. Acad. Sci. 107(35), 1550815511.

Wurster, C.M., Rifai, H., Zhou, B., Haig, J. and Bird, M.I., 2019. Savanna in equatorial Borneo during the late Pleistocene. Sci. Rep. 9(1), 1-7.

Wycherley, P. R. 1973. The phenology of plants in the humid tropics. Micronesia 9, 75-96. 


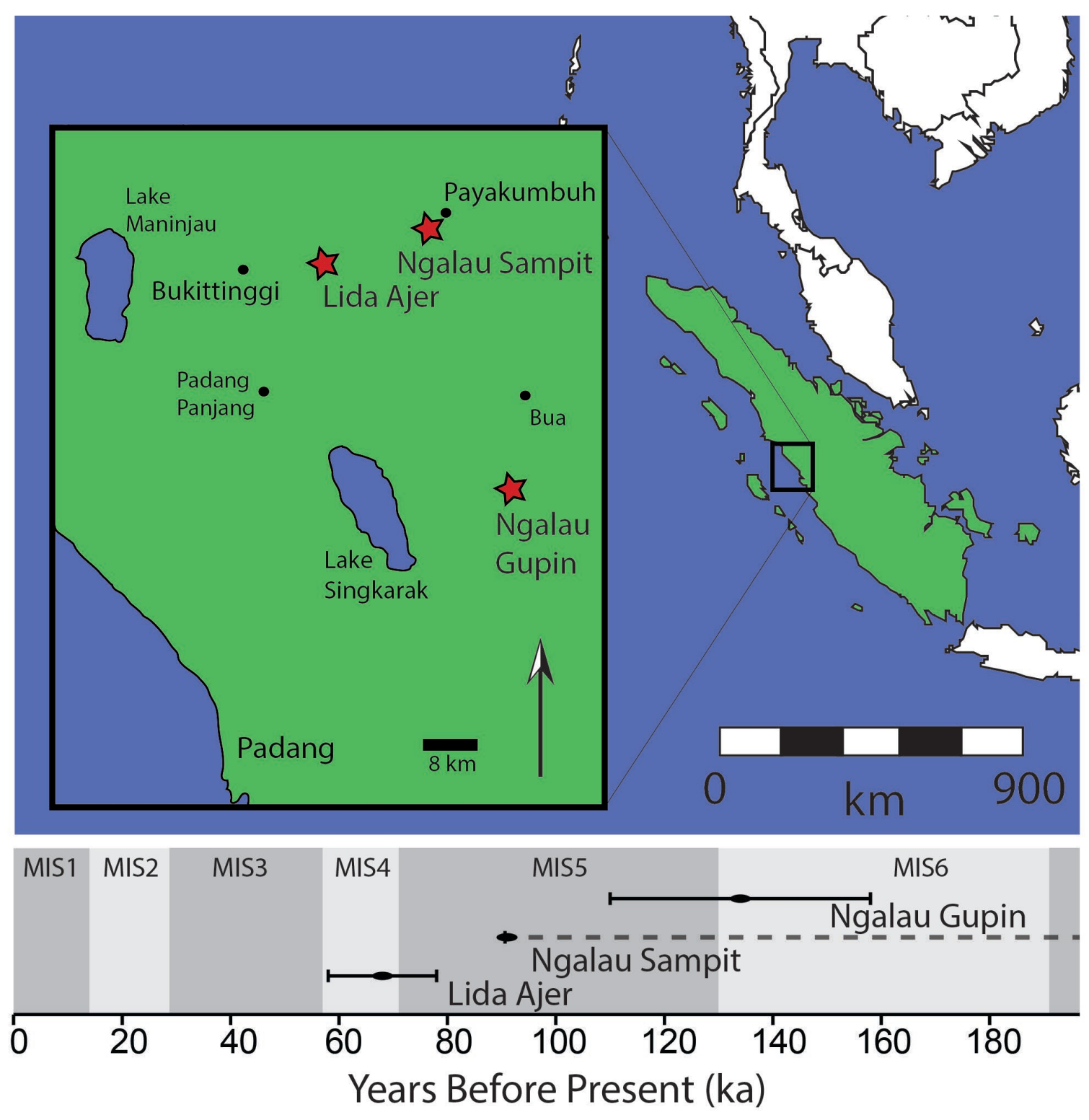

Figure 1. Map of fossil localities yielding orangutan fossils examined in this study, shown relative to major towns and cities in the Padang Highlands. Ages of the sites are illustrated at $2 \sigma$ confidence level (Louys et al. 2017; Westaway et al. 2017; Smith et al. this volume). Ngalau Sampit only has a minimum age (shown via dashed line) although this is considered close to the true age of the deposit. Marine Isotope Stages (Lisiecki and Raymo, 2005) are indicated by the shaded sections of the timeline, MIS1-6 are shown in full. For a list of geographical coordinates see Louys et al. (2017). 

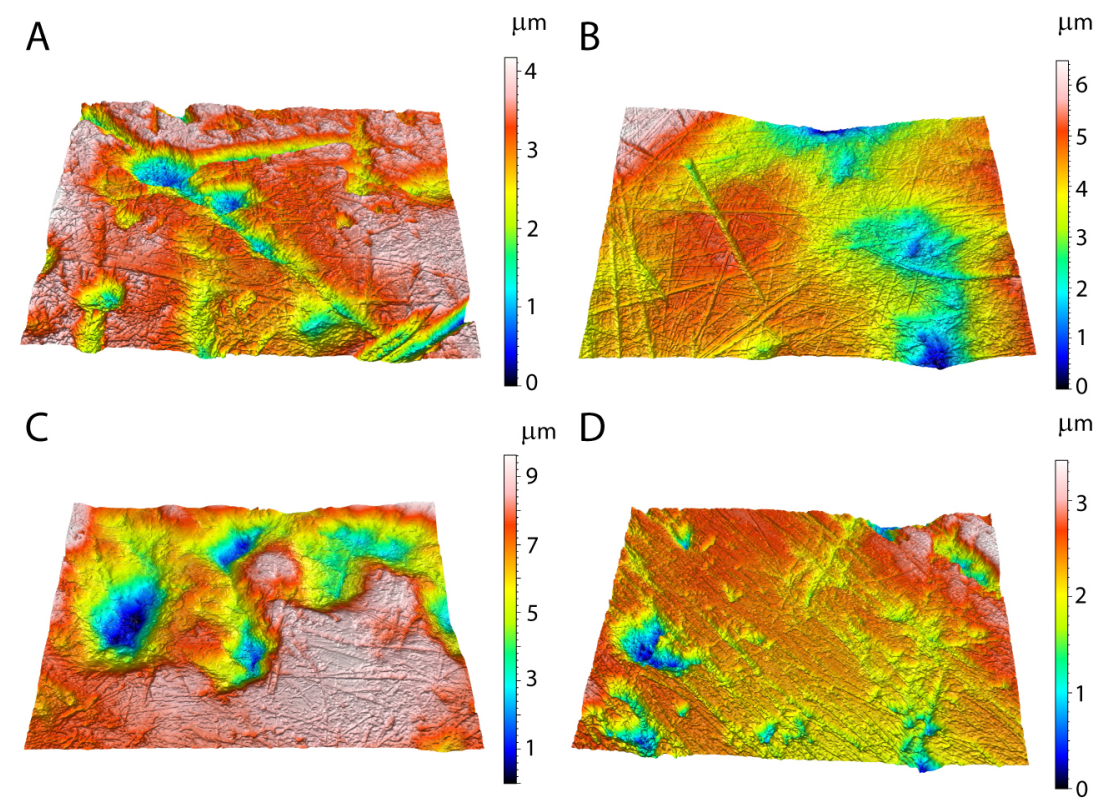

$\mathrm{E}$

$\mathrm{F}$
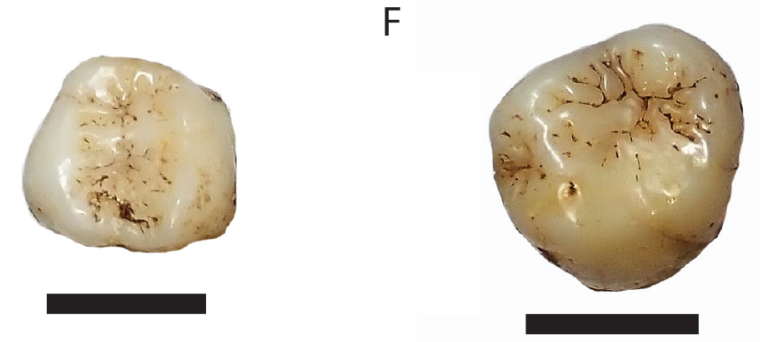

Figure 2. Occlusal surfaces of fossil Pongo from western Sumatra and modern Bornean orangutans. (A)-(D) 3D surface models displaying microwear features of fossil Pongo sp. (A) LA 31, (B) NG 11.44, (C) NS 15.1, and modern Pongo pygmaeus (D) AMNH 146612; (E)-(F) occlusal surfaces of fossil orangutans (E) NG11.17 and (F) NG11.14; scale bar $=1 \mathrm{~cm}$. 

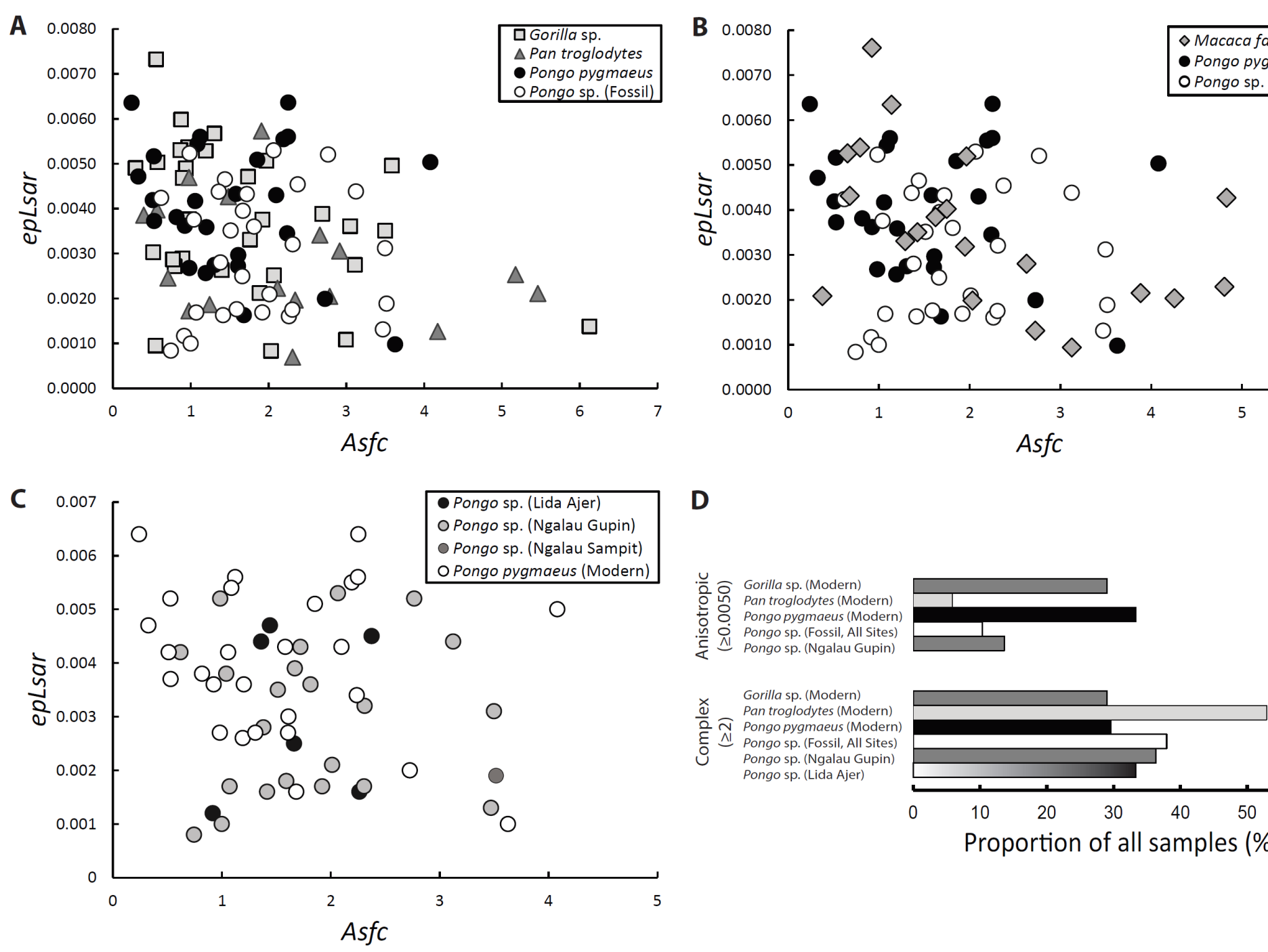

Figure 3. Plot of anisotropy and complexity of all great apes and/or geographically co-occuring taxa compared (including data from Scott et al. 2012) and all fossil and modern specimens of Pongo sp. Bivariate plot of anisotropy and complexity of all great apes examined (A), geographically overlapping orangutans and Macaca fascicularis (B), modern and fossil Pongo specimens examined (C), and a bar graph of the proportion of anisotropic and complex microwear specimens (D). Note, zero specimens of Pongo sp. from Lida Ajer had anisotropic values $(\geq 0.005)$. 
Table 1. List of fossil orangutan specimens examined. Lowercase letters in the Tooth column refer to mandibular teeth, uppercase to maxillary.

\begin{tabular}{|l|l|l|}
\hline Specimen & Site & Tooth \\
\hline LA15.5 & Lida Ajer & ?Lm1 \\
\hline LA15.8 & Lida Ajer & Rm1 \\
\hline LA30 & Lida Ajer & Lm1 \\
\hline LA31 & Lida Ajer & Rp3 \\
\hline LA32 & Lida Ajer & Rm1 \\
\hline LA33 & Lida Ajer & Lm1 \\
\hline NG11.10 & Ngalau Gupin & Lm1 \\
\hline NG11.11 & Ngalau Gupin & RM1 \\
\hline NG11.12 & Ngalau Gupin & Rm2 \\
\hline NG11.14 & Ngalau Gupin & Lm3 \\
\hline NG11.17 & Ngalau Gupin & RM2 \\
\hline NG11.18 & Ngalau Gupin & Rp4 \\
\hline NG11.21 & Ngalau Gupin & RM3 \\
\hline NG11.22 & Ngalau Gupin & P3 \\
\hline NG11.23 & Ngalau Gupin & Rp3 \\
\hline NG11.24 & Ngalau Gupin & LM2 \\
\hline NG11.25 & Ngalau Gupin & Rp3 \\
\hline NG11.26 & Ngalau Gupin & Lm2 \\
\hline
\end{tabular}




\begin{tabular}{|l|l|l|}
\hline NG11.27 & Ngalau Gupin & Lp3 \\
\hline NG11.34 & Ngalau Gupin & RM2 \\
\hline NG11.36 & Ngalau Gupin & RP3 \\
\hline NG11.42 & Ngalau Gupin & p4 \\
\hline NG11.44 & Ngalau Gupin & RM1 \\
\hline NG11.45 & Ngalau Gupin & Lp4 \\
\hline NG11.46 & Ngalau Gupin & Rp4 \\
\hline NG11.47 & Ngalau Gupin & Rp3 \\
\hline NG11.48 & Ngalau Gupin & Rp3 \\
\hline NG15.13 & Ngalau Gupin & ?LM2 \\
\hline NS15.1 & Ngalau Sampit & ?m3 \\
\hline
\end{tabular}


Table 2. DMTA attribute values for all specimens examined or included in statistical comparisons.

\begin{tabular}{|c|c|c|c|c|c|c|c|c|c|}
\hline Taxon & $\mathbf{N}$ & Attribute & Min. & Max. & Range & Median & Mean & SD (n-1) & Normality \\
\hline \multirow[t]{4}{*}{ Gorilla beringei } & 16 & $A s f c$ & 0.518 & 6.124 & 5.606 & 1.182 & 1.711 & 1.455 & 0.001 \\
\hline & & epLsar & 0.0010 & 0.0060 & 0.0050 & 0.0035 & 0.0036 & 0.0015 & 0.499 \\
\hline & & $T f v$ & 0.000 & 19247.120 & 19247.120 & 8997.756 & 9083.769 & 5652.455 & 0.862 \\
\hline & & $H A s f c 81$ & 0.393 & 7.927 & 7.534 & 0.885 & 1.302 & 1.796 & $<0.0001$ \\
\hline \multirow[t]{4}{*}{ Gorilla gorilla } & 15 & $A s f c$ & 0.290 & 3.499 & 3.208 & 1.303 & 1.694 & 1.045 & 0.133 \\
\hline & & epLsar & 0.0008 & 0.0073 & 0.0065 & 0.0038 & 0.0039 & 0.0017 & 0.874 \\
\hline & & $T f v$ & 2091.280 & 22837.300 & 20746.019 & 11806.023 & 9816.945 & 5834.257 & 0.274 \\
\hline & & $H A s f c 81$ & 0.522 & 2.114 & 1.593 & 0.853 & 0.943 & 0.415 & 0.009 \\
\hline \multirow[t]{4}{*}{ Pan troglodytes } & 17 & $A s f c$ & 0.395 & 5.461 & 5.067 & 2.114 & 2.246 & 1.523 & 0.087 \\
\hline & & epLsar & 0.0007 & 0.0057 & 0.0050 & 0.0025 & 0.0028 & 0.0013 & 0.583 \\
\hline & & $T f v$ & 2209.088 & 17398.047 & 15188.959 & 9160.731 & 9428.853 & 4664.934 & 0.726 \\
\hline & & $H A s f c 81$ & 0.505 & 3.535 & 3.030 & 1.210 & 1.339 & 0.719 & 0.008 \\
\hline \multirow[t]{4}{*}{ Pongo pygmaeus } & 27 & $A s f c$ & 0.240 & 4.080 & 3.840 & 1.308 & 1.542 & 0.940 & 0.053 \\
\hline & & epLsar & 0.0010 & 0.0064 & 0.0054 & 0.0042 & 0.0040 & 0.0014 & 0.734 \\
\hline & & $T f v$ & 0.000 & 16947.125 & 16947.125 & 8598.145 & 7160.075 & 5808.400 & 0.006 \\
\hline & & $H A s f c 81$ & 0.402 & 2.170 & 1.768 & 0.782 & 0.902 & 0.437 & 0.001 \\
\hline \multirow[t]{4}{*}{ Pongo sp. } & 29 & $A s f c$ & 0.620 & 3.517 & 2.897 & 1.670 & 1.848 & 0.823 & 0.073 \\
\hline & & epLsar & 0.0008 & 0.0053 & 0.0045 & 0.0031 & 0.0030 & 0.0014 & 0.105 \\
\hline & & $T f v$ & 0.000 & 13718.140 & 13718.140 & 6501.660 & 6630.863 & 4663.229 & 0.641 \\
\hline & & $H A s f c 81$ & 0.295 & 1.000 & 0.705 & 0.481 & 0.540 & 0.216 & 0.220 \\
\hline
\end{tabular}

$\mathrm{N}$, number of specimens sampled; Taxon, species examined; Min., minimum; Max., maximum; Range, total range; SD, standard deviation (n-1); Normality, Shapiro-Wilk, with bold values indicate non-normally distributed data, $\mathrm{p}<0.05$. 
Supplemental Table 1. DMTA attribute values for all specimens here examined or included in statistical comparisons.

\begin{tabular}{|c|c|c|c|c|c|c|c|c|}
\hline Status & Species & Museum & Specimen \# & $A s f c$ & epLsar & $T f v$ & $H A s f c 81$ & \\
\hline Modern & Gorilla beringei & NMNH & 239883 & 0.518 & 0.0030 & 8746.916 & 0.393 & \\
\hline Modern & Gorilla beringei & NMNH & 395636 & 0.968 & 0.0054 & 12259.155 & 1.276 & \\
\hline Modern & Gorilla beringei & NMNH & 396934 & 0.573 & 0.0050 & 2179.473 & 1.172 & \\
\hline Modern & Gorilla beringei & NMNH & 396935 & 0.894 & 0.0029 & 0.000 & 0.844 & \\
\hline Modern & Gorilla beringei & NMNH & 396936 & 6.124 & 0.0014 & 9176.526 & 7.927 & \\
\hline Modern & Gorilla beringei & NMNH & 397351 & 0.790 & 0.0027 & 12211.581 & 0.926 & \\
\hline Modern & Gorilla beringei & NMNH & 397358 & 1.884 & 0.0021 & 15793.107 & 0.482 & \\
\hline Modern & Gorilla beringei & NMNH & 545027 & 0.876 & 0.0060 & 11501.098 & 0.694 & \\
\hline Modern & Gorilla beringei & NMNH & 545028 & 1.920 & 0.0038 & 19247.120 & 1.166 & \\
\hline Modern & Gorilla beringei & NMNH & 545030 & 0.548 & 0.0010 & 5384.083 & 0.431 & \\
\hline Modern & Gorilla beringei & NMNH & 545031 & 3.585 & 0.0050 & 15457.481 & 0.960 & \\
\hline Modern & Gorilla beringei & NMNH & 545032 & 1.763 & 0.0033 & 13374.805 & 1.514 & \\
\hline Modern & Gorilla beringei & NMNH & 545034 & 1.973 & 0.0051 & 5986.510 & 0.682 & \\
\hline Modern & Gorilla beringei & NMNH & 545035 & 0.866 & 0.0053 & 539.299 & 1.104 & \\
\hline Modern & Gorilla beringei & NMNH & 545036 & 1.397 & 0.0026 & 4664.171 & 0.623 & \\
\hline Modern & Gorilla beringei & NMNH & 545037 & 2.689 & 0.0039 & 8818.985 & 0.629 & \\
\hline Modern & Gorilla gorilla & AMNH & 167325 & 2.068 & 0.0025 & 6437.311 & 0.577 & \\
\hline Modern & Gorilla gorilla & AMNH & 167327 & 3.499 & 0.0035 & 15301.801 & 0.853 & \\
\hline Modern & Gorilla gorilla & AMNH & 167330 & 2.030 & 0.0008 & 2640.854 & 0.522 & \\
\hline Modern & Gorilla gorilla & AMNH & 167332 & 1.736 & 0.0047 & 3813.055 & 0.644 & \\
\hline Modern & Gorilla gorilla & AMNH & 167334 & 3.109 & 0.0027 & 7864.378 & 0.901 & \\
\hline Modern & Gorilla gorilla & AMNH & 167339 & 1.303 & 0.0057 & 14611.653 & 0.770 & \\
\hline Modern & Gorilla gorilla & AMNH & 170362 & 3.047 & 0.0036 & 13268.739 & 1.254 & \\
\hline Modern & Gorilla gorilla & AMNH & 200501 & 0.981 & 0.0038 & 22837.300 & 0.799 & \\
\hline Modern & Gorilla gorilla & CMNH & B1075 & 0.555 & 0.0073 & 12127.773 & 0.733 & \\
\hline Modern & Gorilla gorilla & $\mathrm{CMNH}$ & B1076 & 1.192 & 0.0053 & 2091.280 & 0.880 & \\
\hline Modern & Gorilla gorilla & $\mathrm{CMNH}$ & B1181 & 0.937 & 0.0049 & 13166.423 & 0.578 & \\
\hline Modern & Gorilla gorilla & $\mathrm{CMNH}$ & B1410 & 0.895 & 0.0047 & 3878.580 & 0.979 & \\
\hline Modern & Gorilla gorilla & CMNH & B1419 & 2.994 & 0.0011 & 11806.023 & 2.114 & \\
\hline Modern & Gorilla gorilla & CMNH & B1899 & 0.290 & 0.0049 & 5440.732 & 1.476 & \\
\hline Modern & Gorilla gorilla & CMNH & B1908 & 0.771 & 0.0029 & 11968.269 & 1.062 & \\
\hline Modern & Macaca fascicularis & NMNH & 13169 & 3.125 & 0.0009 & 14459.474 & 0.616 & \\
\hline Modern & Macaca fascicularis & NMNH & 114410 & 2.722 & 0.0013 & 14535.539 & 1.154 & \\
\hline Modern & Macaca fascicularis & NMNH & 125102 & 2.031 & 0.0020 & 10539.273 & 1.167 & \\
\hline Modern & Macaca fascicularis & NMNH & 121803 & 4.255 & 0.0020 & 10337.286 & 3.976 & \\
\hline Modern & Macaca fascicularis & NMNH & 198300 & 0.377 & 0.0021 & 8241.357 & 1.244 & \\
\hline Modern & Macaca fascicularis & NMNH & 141145 & 3.883 & 0.0022 & 13739.876 & 1.852 & \\
\hline Modern & Macaca fascicularis & NMNH & 144505 & 4.806 & 0.0023 & 12926.521 & 0.684 & \\
\hline
\end{tabular}




\begin{tabular}{|c|c|c|c|c|c|c|c|c|}
\hline Modern & Macaca fascicularis & NMNH & 114411 & 2.626 & 0.0028 & 10398.090 & 0.977 & \\
\hline Modern & Macaca fascicularis & NMNH & 196815 & 1.948 & 0.0032 & 13014.691 & 0.670 & \\
\hline Modern & Macaca fascicularis & NMNH & 317191 & 1.289 & 0.0033 & 14835.882 & 0.686 & \\
\hline Modern & Macaca fascicularis & NMNH & 175896 & 1.424 & 0.0035 & 7542.977 & 0.642 & \\
\hline Modern & Macaca fascicularis & NMNH & 292555 & 1.624 & 0.0038 & 15017.728 & 0.839 & \\
\hline Modern & Macaca fascicularis & NMNH & 143583 & 1.747 & 0.0040 & 13611.024 & 0.967 & \\
\hline Modern & Macaca fascicularis & NMNH & 83944 & 4.830 & 0.0043 & 15299.894 & 1.462 & \\
\hline Modern & Macaca fascicularis & NMNH & 198301 & 0.679 & 0.0043 & 850.585 & 0.887 & \\
\hline Modern & Macaca fascicularis & NMNH & 121802 & 1.964 & 0.0052 & 8853.760 & 1.915 & \\
\hline Modern & Macaca fascicularis & NMNH & 196827 & 0.653 & 0.0053 & 7594.230 & 0.504 & \\
\hline Modern & Macaca fascicularis & NMNH & $34913 / 19192$ & 0.793 & 0.0054 & 1626.060 & 0.839 & \\
\hline Modern & Macaca fascicularis & NMNH & 144419 & 1.139 & 0.0063 & 14831.804 & 0.947 & \\
\hline Modern & Macaca fascicularis & NMNH & 34914 & 0.923 & 0.0076 & 11253.216 & 1.415 & \\
\hline Modern & Pan troglodytes & CMNH & B1722upper & 0.977 & 0.0017 & 7343.722 & 0.505 & \\
\hline Modern & Pan troglodytes & CMNH & B1903upper & 2.659 & 0.0034 & 4096.568 & 1.457 & \\
\hline Modern & Pan troglodytes & CMNH & B1956upper & 2.308 & 0.0007 & 6762.212 & 1.172 & \\
\hline Modern & Pan troglodytes & CMNH & B2027upper & 2.341 & 0.0020 & 9245.959 & 1.956 & \\
\hline Modern & Pan troglodytes & CMNH & B2033lower & 0.566 & 0.0040 & 6147.559 & 0.764 & \\
\hline Modern & Pan troglodytes & CMNH & B2034upper & 4.174 & 0.0013 & 9160.731 & 1.488 & \\
\hline Modern & Pan troglodytes & CMNH & B2756upper & 2.114 & 0.0022 & 12601.933 & 0.937 & \\
\hline Modern & Pan troglodytes & CMNH & B2771 & 0.395 & 0.0039 & 4569.624 & 1.513 & \\
\hline Modern & Pan troglodytes & CMNH & B3398upper & 1.242 & 0.0019 & 17398.047 & 0.541 & \\
\hline Modern & Pan troglodytes & CMNH & B3412 & 2.785 & 0.0020 & 3276.291 & 1.525 & \\
\hline Modern & Pan troglodytes & $\mathrm{CMNH}$ & B3413upper & 1.484 & 0.0043 & 15167.619 & 0.828 & \\
\hline Modern & Pan troglodytes & CMNH & B3418upper & 0.707 & 0.0025 & 11257.337 & 1.202 & \\
\hline Modern & Pan troglodytes & CMNH & B3434 & 5.461 & 0.0021 & 16422.856 & 3.535 & \\
\hline Modern & Pan troglodytes & CMNH & B3437 & 5.174 & 0.0025 & 13897.522 & 1.210 & \\
\hline Modern & Pan troglodytes & $\mathrm{CMNH}$ & B3537upper & 0.977 & 0.0047 & 2209.088 & 1.377 & \\
\hline Modern & Pan troglodytes & CMNH & B3538upper & 2.914 & 0.0031 & 9075.805 & 2.017 & \\
\hline Modern & Pan troglodytes & CMNH & B3553upper & 1.908 & 0.0057 & 11657.619 & 0.739 & \\
\hline Modern & Pongo pygmaeus & SAPM & 1981103 & 0.326 & 0.0047 & 2093.714 & 0.782 & \\
\hline Modern & Pongo pygmaeus & SAPM & 1981106 & 3.627 & 0.0010 & 8713.198 & 2.170 & \\
\hline Modern & Pongo pygmaeus & SAPM & 1981111 & 0.240 & 0.0064 & 1886.291 & 0.590 & \\
\hline Modern & Pongo pygmaeus & SAPM & 1981113 & 1.192 & 0.0026 & 12544.071 & 1.611 & \\
\hline Modern & Pongo pygmaeus & SAPM & 1981145 & 1.122 & 0.0056 & 13093.951 & 0.662 & \\
\hline Modern & Pongo pygmaeus & SAPM & 1981147 & 0.530 & 0.0037 & 16015.377 & 0.896 & \\
\hline Modern & Pongo pygmaeus & SAPM & 198159 & 2.726 & 0.0020 & 8174.687 & 1.990 & \\
\hline Modern & Pongo pygmaeus & SAPM & 198162 & 0.818 & 0.0038 & 27.923 & 0.701 & \\
\hline Modern & Pongo pygmaeus & SAPM & 198174 & 2.193 & 0.0055 & 1818.750 & 0.964 & \\
\hline Modern & Pongo pygmaeus & SAPM & 198178 & 1.854 & 0.0051 & 8598.145 & 0.927 & \\
\hline Modern & Pongo pygmaeus & SAPM & 198188 & 0.925 & 0.0036 & 2066.095 & 0.622 & \\
\hline Modern & Pongo pygmaeus & SAPM & 198190 & 1.683 & 0.0016 & 546.325 & 1.281 & \\
\hline
\end{tabular}




\begin{tabular}{|c|c|c|c|c|c|c|c|}
\hline Modern & Pongo pygmaeus & SAPM & 198196 & 0.982 & 0.0027 & 16947.125 & 0.655 \\
\hline Modern & Pongo pygmaeus & SAPM & 198197 & 1.608 & 0.0027 & 10877.960 & 1.145 \\
\hline Modern & Pongo pygmaeus & SAPM & 198199 & 0.512 & 0.0042 & 637.181 & 0.918 \\
\hline Modern & Pongo pygmaeus & AMNH & 140426 & 1.308 & 0.0027 & 14984.061 & 0.629 \\
\hline Modern & Pongo pygmaeus & AMNH & 146612 & 1.582 & 0.0043 & 642.274 & 0.569 \\
\hline Modern & Pongo pygmaeus & AMNH & 18010 & 1.087 & 0.0054 & 10273.562 & 0.519 \\
\hline Modern & Pongo pygmaeus & AMNH & 200898 & 1.202 & 0.0036 & 1562.249 & 1.093 \\
\hline Modern & Pongo pygmaeus & AMNH & 200900 & 1.611 & 0.0030 & 11219.461 & 0.518 \\
\hline Modern & Pongo pygmaeus & $\overline{\mathrm{AMNH}}$ & 28252 & 0.527 & 0.0052 & 0.000 & 0.836 \\
\hline Modern & Pongo pygmaeus & AMNH & 28253 & 1.058 & 0.0042 & 3661.846 & 1.055 \\
\hline Modern & Pongo pygmaeus & ZRC & 4742 & 2.250 & 0.0056 & 65.563 & 0.624 \\
\hline Modern & Pongo pygmaeus & ZRC & $4746 \mathrm{~L}$ & 2.099 & 0.0043 & 8679.812 & 0.775 \\
\hline Modern & Pongo pygmaeus & ZRC & $4750 \mathrm{~L}$ & 2.239 & 0.0034 & 13355.620 & 0.428 \\
\hline Modern & Pongo pygmaeus & ZRC & $4754 \mathrm{~L}$ & 2.253 & 0.0064 & 13701.007 & 0.402 \\
\hline Modern & Pongo pygmaeus & ZRC & $4755 \mathrm{~L}$ & 4.080 & 0.0050 & 11135.791 & 0.981 \\
\hline Fossil & Pongo sp. & Fossils & LA15.5 & 1.441 & 0.0047 & 11061.775 & 0.478 \\
\hline Fossil & Pongo sp. & Fossils & LA15.8 & 0.916 & 0.0012 & 5539.440 & 0.315 \\
\hline Fossil & Pongo sp. & Fossil & LA30 & 1.361 & 0.0044 & 1344.109 & 0.410 \\
\hline Fossil & Pongo sp. & Fossil & LA31 & 2.375 & 0.0045 & 2453.754 & 0.809 \\
\hline Fossil & Pongo sp. & Fossil & LA32 & 1.663 & 0.0025 & 7731.573 & 0.387 \\
\hline Fossil & Pongo sp. & Fossil & LA33 & 2.263 & 0.0016 & 27.925 & 0.398 \\
\hline Fossil & Pongo sp. & Fossil & NG11.10 & 1.921 & 0.0017 & 2442.613 & 0.314 \\
\hline Fossil & Pongo sp. & Fossil & NG11.11 & 1.721 & 0.0043 & 12496.907 & 0.498 \\
\hline Fossil & Pongo sp. & Fossil & NG11.12 & 1.041 & 0.0038 & 0.000 & 0.688 \\
\hline Fossil & Pongo sp. & Fossil & NG11.14 & 1.382 & 0.0028 & 5259.057 & 0.481 \\
\hline Fossil & Pongo sp. & Fossil & NG11.17 & 1.670 & 0.0039 & 11255.521 & 0.387 \\
\hline Fossil & Pongo sp. & Fossil & NG11.18 & 0.985 & 0.0052 & 877.815 & 0.602 \\
\hline Fossil & Pongo sp. & Fossil & NG11.21 & 2.066 & 0.0053 & 13718.140 & 0.564 \\
\hline Fossil & Pongo sp. & Fossil & NG11.22 & 2.766 & 0.0052 & 10043.602 & 0.952 \\
\hline Fossil & Pongo sp. & Fossil & NG11.23 & 2.311 & 0.0032 & 5786.197 & 0.947 \\
\hline Fossil & Pongo sp. & Fossil & NG11.24 & 1.814 & 0.0036 & 6924.177 & 0.467 \\
\hline Fossil & Pongo sp. & Fossil & NG11.25 & 3.498 & 0.0031 & 7190.850 & 0.988 \\
\hline Fossil & Pongo sp. & Fossil & NG11.26 & 3.471 & 0.0013 & 11365.749 & 0.483 \\
\hline Fossil & Pongo sp. & Fossil & NG11.27 & 0.744 & 0.0008 & 6501.660 & 0.357 \\
\hline Fossil & Pongo sp. & Fossil & NG11.34 & 0.999 & 0.0010 & 13106.521 & 0.386 \\
\hline Fossil & Pongo sp. & Fossil & NG11.36 & 1.592 & 0.0018 & 5270.534 & 0.515 \\
\hline Fossil & Pongo sp. & Fossil & NG11.42 & 1.415 & 0.0016 & 167.550 & 0.401 \\
\hline Fossil & Pongo sp. & Fossil & NG11.44 & 2.306 & 0.0017 & 10752.185 & 0.295 \\
\hline Fossil & Pongo sp. & Fossil & NG11.45 & 0.620 & 0.0042 & 418.372 & 0.300 \\
\hline Fossil & Pongo sp. & Fossil & NG11.46 & 1.514 & 0.0035 & 5293.602 & 0.754 \\
\hline Fossil & Pongo sp. & Fossil & NG11.47 & 3.124 & 0.0044 & 7851.160 & 0.569 \\
\hline Fossil & Pongo sp. & Fossil & NG11.48 & 2.012 & 0.0021 & 13526.722 & 0.433 \\
\hline
\end{tabular}




\begin{tabular}{|c|c|c|c|c|c|c|c|}
\hline Fossil & Pongo sp. & Fossils & NG15.13 & 1.071 & 0.0017 & 1114.121 & 0.494 \\
\hline Fossil & Pongo sp. & Fossils & NS15.1 & 3.517 & 0.0019 & 12773.406 & 1.000 \\
\hline
\end{tabular}

